\title{
PLASMA CONCENTRATIONS OF OXYTETRACYCLINE IN ELEPHANTS FOLLOWING INTRAVENOUS AND INTRAMUSCULAR ADMINISTRATION OF TERRAMYCIN/LA INJECTABLE SOLUTION
}

M. LIMPOKA, P. CHAI ANAN, S. SIRIVEJPANDU, R. KANCHANOMAI, S. RATTANAMONTHIANCHAI*, P. PUANGKUM**

Faculty of Veterinary Medicine, Kasetsart University, Bangkok, * Agricultural Technical Service, Pfizer International Corporation (S.A.), and ** Veterinary section, Northern .Timber Working, Forestry .Industry Organization, Lumpang, Thailand

Received October 3, 1985

\section{Abstract}

L 1 m p o k a M., P. C h a $1-a$ n a n,

S. $S i r i v$ e $j$ p a d u, R. $K$ a n $\mathrm{h}$ a $n$ o m a 1 ,

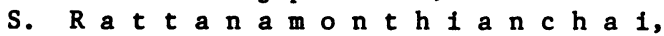

P. $P$ a $n \& \mathrm{k}$ u: Plasma Concentrations of Oxytetracycline in Elephants Following Intravenous and Intramuscular Administration of Terramycin/La Injectable Solution. Acta vet. Brno,56,1987:173-179.

The blood concentrations of oxytetracycline were studied in Asian elephants following the intravenous and intramuscular administration of Terramycin/LA solution. The drug was administered as $200 \mathrm{mg}$ oxytetracycline base/m1 in aqueous 2 - pyrrolidone at a dosage of $20 \mathrm{mg} / \mathrm{kg}$ body mass. The blood samples were collected from the ear veins of each animal. Plasma concentrations of oxytetracycline were analysed by microbiological method and high pressure liquid chromatography.

An average peak plasma concentration of $6.2 \mu \mathrm{g} / \mathrm{ml}$ was obtained in one hour following intravenous administration in elephants. No oxytetracycline was detected in plasma after the 60 th post dosing hour. The average peak plasma concentration of $2.87 \mu \mathrm{g} / \mathrm{ml}$ was found in two hours following intramuscular injection of the drug. Concentrations exceeding $1 \mu \mathrm{g} / \mathrm{ml}$ were maintained for 48 hours after intramuscular dose. The drug was shown to result in sustained oxytetracycline blood concentrations over a three-day period following a single intramuscular administration of the drug to elephants.

Administration route, post-injection time, OTC, elephants.

Asian elephants are susceptible to a number of diseases for which antimicrobial drugs are recommended. The correct drugs prescribed, proper dosage and proper interval in elephants are still questions. Too of ten, failure to treat an illness in elephants is caused by the inability of the 
veterinarian to administer adequate doses and appropriate intervals of the drugs. S $c h \mathrm{~m} \mathrm{I} \mathrm{d} t$ (1978) proposed that elephants weighing the same as cattle and horses can be given the same dosage per unit of body mass, and 0.5 or 0.75 the recommended dose can be given to adult elephants.

In this study, blood concentrations of oxytetracycline were investigatif in Asian elephants following intravenous and intramuscular administration of $200 \mathrm{mg}$ oxytetracycline base/ml in aqueous 2 - pyrrolidone at a dosage of $20 \mathrm{mg} / \mathrm{kg}$ body mass. Results obtained could be used as a guideline for recommended dosage regimen for clinical use of this antibiotic in elephants.

\section{Materials and Methods}

\section{Animals}

Six healthy Asian elephants ${ }^{1}$ weighing $2.030-3.475 \mathrm{~kg}$ were used in this study. The animals were acclimatized for 2 weeks around the experimental area ${ }^{2}$. The cannula ${ }^{3}$ was placed in the right ear vein of each animal prior to drug administration. The animals were randomly assigned to two groups.

Drug administration and blood collection

The drug used in this study was Terramycin/LA injectable solution 4 at the concentration of $200 \mathrm{mg}$ of oxytetracycline base (OTC) $/ \mathrm{ml}$. The first three elephants received $10 \mathrm{ml}$ of the drug/100 $\mathrm{kg}$ body mass intravenously via the cannula. The three remaining elephants received the same dosage of Terramycin/LA solution intramuscularly. The deep muscular injection was distributed bilaterally in the hind quarters. No more than $30 \mathrm{ml}$ of Terramycin/LA solution was injected into individual site. Disposable 3 in, 16 ga needles were used to inject the drug. No tranquilizer was given prior to drug administration or the collection of blood samples. The elephants were chained by one front leg to a fixed point only to obtain the blood samples.

Following drug administration, blood samples were collected in heparinized syringes at $0,1,2,3,4,6,8,12,18,24,36,48,60,84,108,132$ hours post dosing. The blood samples were collected from the veins located on the posterior surface of the ears. After collection, the blood was centrifuged and the plasma was immediately frozen until assay.

Analytical method

Plasma samples were analysed for OTC by a microbiological method. The microbiological assays were carried out in $150 \times 20 \mathrm{~mm}$ petri dishes, with reference organism Bacillus cereus ATCC No. $1178^{5}$ ( $B$ e $n n$ e t $t$ et al. 1966). The limit of sensitivity of the method is $0.25 \mu \mathrm{g} / \mathrm{ml}$.

Selected plasma samples were also analysed by high pressure liquid chromatography 6 (HPLC) ( $\mathrm{S} \mathrm{har} \mathrm{m} \mathrm{a} \mathrm{and} \mathrm{B}$ e vill 1978). The concentrations of OTC in plasma determined by microbiological assay were

1 Northern Timber Working, Forestry Industry Organization (FIO) Lunipang, Thailand '

2 Thung Kwan Plant Collection Station, FIO, Lumpang, Thailand

3 Intrademic ${ }^{R}$ Polyethylene tubing, Medical Formulation, CAT. No. PE 90 (7421), I.D. .043"

4 Pfizer International Corporation (S.A.), Bangkok, Thailand

5 Department of Microbiology, Faculty of Science, Kasetsart University, Bangkok, Thailand

6 The Varian's 5.000. Series liquid chromatographs with the CDS 401 Data system (VARIAN, VISTA 54), equipped with MicroPak $\mathrm{CH}-10$ and UV- 5 Selectable Wavelength detector 
Table 1

Concentrations of oxytetracycline in elephant plasma following the intravenous administration of $20 \mathrm{mg}$ Terracyclin/LA solution/ kilogram of body mass.

\begin{tabular}{|c|ccc|c|c|}
\hline \multirow{2}{*}{ Time } & \multicolumn{3}{|c|}{ Animal number } & \multirow{2}{*}{ Mean $^{\mathrm{a}}$} & \multirow{2}{*}{ S.D. ${ }^{\mathbf{b}}$} \\
\cline { 2 - 4 } (hours) & 1 & 2 & 3 & & \\
\hline 1.0 & 7.09 & 5.64 & 5.84 & 6.19 & 0.64 \\
2.0 & 5.64 & 3.61 & 3.61 & 4.28 & 0.95 \\
3.0 & 3.61 & 2.51 & -- & 3.06 & 0.55 \\
4.0 & 2.68 & 1.87 & 2.44 & 2.33 & 0.33 \\
6.0 & 2.16 & 1.17 & 1.52 & 1.62 & 0.40 \\
8.0 & 1.28 & 0.71 & 1.28 & 1.09 & 0.26 \\
12.0 & 1.03 & 0.35 & 1.17 & 0.85 & 0.35 \\
18.0 & $<0.25$ & $<0.25$ & 0.35 & 0.28 & 0.03 \\
24.0 & $<0.25$ & $<0.25$ & $<0.25$ & $<0.25$ & -- \\
36.0 & $<0.25$ & $<0.25$ & -- & $<0.25$ & -- \\
48.0 & $<0.25$ & $<0.25$ & - & $<0.25$ & -- \\
60.0 & 0 & 0 & 0 & 0 & -- \\
\hline
\end{tabular}

\section{a Expressed as $\mu \mathrm{g} / \mathrm{ml}$}

b Standard deviation

Table 2

Plasma concentrations of oxytetracycline in one elephant following intravenous administration, determined by HPLC and microbiological assay

\begin{tabular}{|c|cc|}
\hline \multirow{2}{*}{ Time } & \multicolumn{2}{|c|}{ Elephant No. 3 } \\
\cline { 2 - 3 } (hours) & Microbiological & HPLC \\
\hline 1.0 & 5.84 & 5.13 \\
2.0 & 3.60 & 2.95 \\
4.0 & 2.44 & 2.11 \\
8.0 & 1.28 & 1.92 \\
12.0 & 1.17 & 1.63 \\
24.0 & $<0.25$ & 0.95 \\
36.0 & $<0.25$ & 0.56 \\
\hline
\end{tabular}


Table 3

Concentrations of oxytetracycline in elephant plasma following the intramuscular administration of $20 \mathrm{mg}$ Terramycin/LA solution/ kilogram of body mass

\begin{tabular}{|c|ccc|c|c|}
\hline \multirow{2}{*}{ Time } & \multicolumn{3}{|c|}{ An1ma1 number } & Mean $^{\mathrm{a}}$ & S.D. $^{\mathrm{b}}$ \\
\cline { 2 - 4 } (hours) & 4 & 5 & 6 & & \\
\hline 1.0 & 2.21 & 2.68 & 2.91 & 2.6 & 0.29 \\
2.0 & 2.44 & 3.60 & 2.96 & 2.87 & 0.52 \\
3.0 & 2.21 & 3.00 & 1.75 & 2.32 & 0.51 \\
4.0 & 2.44 & 2.44 & 1.98 & 2.28 & 0.21 \\
6.0 & 2.44 & 1.40 & 1.86 & 1.90 & 0.42 \\
8.0 & 1.86 & 1.28 & 1.05 & 1.39 & 0.34 \\
12.0 & 1.86 & 1.17 & 1.05 & 1.36 & 0.35 \\
18.0 & 1.86 & 1.75 & 1.86 & 1.82 & 0.05 \\
24.0 & 1.63 & 1.28 & 2.44 & 1.78 & 0.48 \\
36.0 & 1.28 & 0.93 & 2.44 & 1.55 & 0.64 \\
48.0 & 0.72 & 0.82 & 1.75 & 1.09 & 0.46 \\
60.0 & $<0.25$ & 0.36 & 1.40 & 0.67 & 0.52 \\
84.0 & $<0.25$ & 0.70 & 0.70 & 0.55 & 0.21 \\
108.0 & $<0.25$ & $<0.25$ & $<0.25$ & $<0.25$ & -- \\
132.0 & $<0.25$ & $<0.25$ & $<0.25$ & $<0.25$ & - \\
\hline
\end{tabular}

a Expressed as $\mu \mathrm{g} / \mathrm{ml}$

b Standard deviation

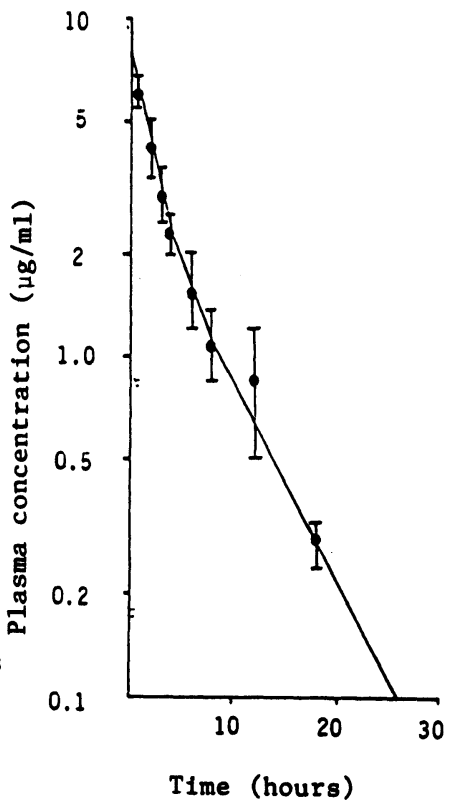

Fig. I: The average plasma concentrations of oxytetracycline following the intravenous administration of $20 . \mathrm{mg}$ Terramycin/LA solution/ $\mathrm{kg}$ body mass to 3 elephants. 


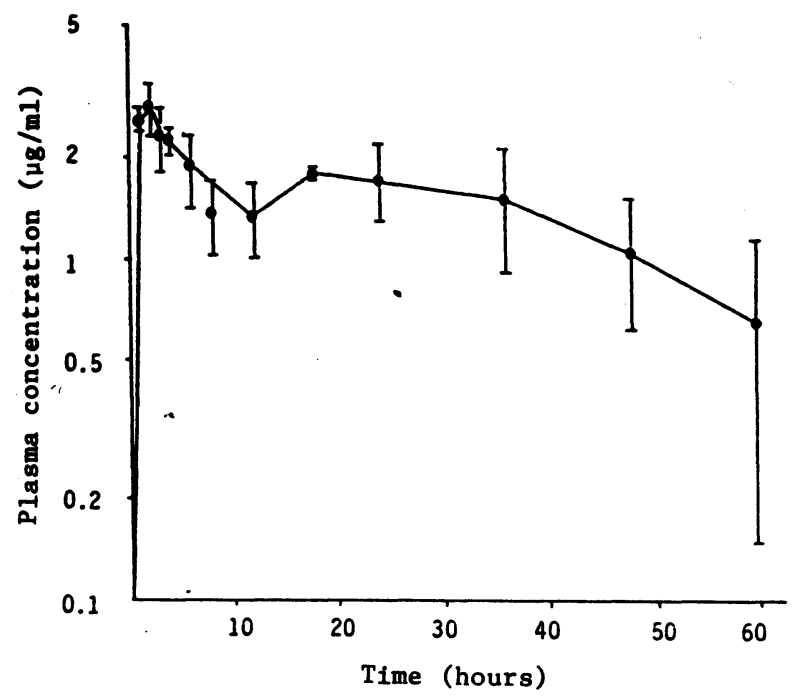

F1g. 2: The average plasma concentrations of oxytetracycline following the i.m. administration of $20 \mathrm{mg}$ Terramycin/LA solution/kg body mass to 3 elephants.

used in data analysis. Good correlation was found between the 2 assay methods.

The data was calculated on a SHARP PC - 1500 with plotter/ Cassette Interface and CE - 502 A Statistics Library.

\section{Results and Discussion}

The average plasma concentrations for intravenous injection of Terramycin $/ \mathrm{LA}$ at $20 \mathrm{mg} / \mathrm{kg}$ body mass to elephants are shown in Table 1. One hour following drug administration an average plasma concentration of oxytetracycline was $6.19 \mu \mathrm{g} / \mathrm{ml}$. The drug in plasma decreased with time and reached $0.28 \mu \mathrm{g} / \mathrm{ml}$ (approximate limit of detection) about 18 hours after dosing. Concentrations exceeding $1 \mu \mathrm{g} / \mathrm{ml}$ were maintained for at least 8 hours following intravenous administration. A semilogarithmic plot of the average plasma concentrations at specific times following intravenous drug administration is illustrated in Figure 1.

The high pressure liquid chromatographic procedure was used to confirm the quantitation of oxytetracycline in plasma and to detect the presence of any metabolites. The concentrations of oxytetracycline in plasma of eleph nt no. 3, determined by both HPLC and the microbiological assay, are shown in Table 2. No metabolites were found in plasma of elephants receiving Terramycin/LA solution.

The individual and average concentrations of oxytetracycline in plasma following intramuscular administration of $20 \mathrm{mg}$ Terramycin/LA/ kg body mass to elephants are presented in Table 2. The average peak concentration of oxytetracycline in plasma was $2.87 \mu \mathrm{g} / \mathrm{ml}$. This maximum value occurred two hours following drug administration. As shown in Table 3 , the oxytetracycline concentration in plasma varied from $2.4-3.6 \mu \mathrm{g} / \mathrm{ml}$ among individual animals 
at two hours. The concentrations exceeding $1 \mu \mathrm{g} / \mathrm{ml}$ were maintained at least for 48 hours following intramuscular dosing. A semilogarithmic plot of an average plasma concentration vs time is presented in Figure 2.

After intramuscular injection of $20 \mathrm{mg} / \mathrm{kg}$ of the Terramycin/LA solution to elephants, peak plasma levels were achieved between 1 and 48 hours and ranged from $1.09-2.87 \mu \mathrm{g} / \mathrm{ml}$ (Table 3). Plasma concentrations were higher than the minimal inhibitory concentrations (MIC) reported for most susceptible pathogens $(0.5 \mathrm{\mu g} / \mathrm{ml}$ OTC) for approximately 84 hours, except for $E$. coli. The MIC values for $E$. coli have been reported to be $4 \mu \mathrm{g} / \mathrm{ml}$ for OTC in a calf ( $G$ a $r$ r o d et al. 1973; A $t \mathrm{k} i \mathrm{n}$ o $\mathrm{n} 1983$; $\mathrm{B}$ a $\mathrm{r} r \mathrm{y}$ and $\mathrm{T} h \circ \mathbf{r} \mathrm{n}$ e $\mathbf{r}$ r y 1980; $\mathrm{R}$ o $\mathrm{s}$ e $\mathrm{n}$ b l a t $\mathrm{t} 1980$ ), and this organism would probably be little affected on the i.m. dose employed.

It appears that the drug was rapidly absorbed and was shown to result in sustained OTC blood concentrations over a three-day period in elephants following a single intramuscular injection of $20 \mathrm{mg} / \mathrm{kg}$ body mass. It is possible to compare the results in elephants with those reported elsewhere in cattle, sheep and swine (Technical Information, Agricultural Development Division, Pfizer Ltd. 1978 - 1981).

Koncentrace oxytetracyklinu $\mathbf{v}$ krvi slonů po intravenozní aplikaci Terramycinu/LA

U 6 asijských slonů (o živé hmotnosti 2030 - 3475 kg) byla sledována koncentrace oxytetracyklinu (OTC) v krvi po intravenózní a intramuskulární aplikaci roztoku Terramycinu/LA. Léčivo bylo podáváno $\mathrm{v}$ dávce $20 \mathrm{mg} \cdot \mathrm{kg}^{-1}$ živé hmotnosti ve vodném 2-pyrrolidonu (200 $\mathrm{mg}$ oxytetracyklinu/ml). Vzorky krve byly $u$ všech zvířat odebírány $z$ ušních žil. Koncentrace oxytetracyklinu v krevní plazmě byly stanoveny metodou mikrobiologickou a vysokotlakou kapalinovou chromatografií.

Po iv. aplikaci byla průměrná nejvyšší koncentrace $\mathrm{v}$ plazmě slonů za $1 \mathrm{~h}$, po $60 \mathrm{~h}$ OTC $\mathrm{v}$ plazmě již prokázán nebyl. Po im. podání byla 'zjištěna nejvyšší koncentrace OTC, $2,87^{\mu \mathrm{g} \cdot \mathrm{ml}^{-1}} \mathrm{za} 2 \mathrm{~h}$ po podáríi léčiva. Koncentrace přesahující $1 \mu \mathrm{g} \cdot \mathrm{ml}^{-1}$ se udržovala $48 \mathrm{~h}$ po aplikaci OTC. Jediná im. aplikace léčiva tedy byla dostatečná $k$ udržení účinné koncentrace OTC $v$ krvi slonů.

Концентрация окситетрациклина в крови слонов после внутривенной дачи террамицина/ла

у 6 азиатских слонов (живой массы 2030 - 3475 кг) проводились исследования концентрации окситетрациклина (ОТц) в крови после бнутривенного и внутримышечного введения раствора террамицина/ла. Медикамент давали дозой 20 мг.кГ-1 живой массы в водном 2-пирролидоне (200 мг окситетрациклина/мл). Образцы крови у всех животных из ушных вен. Определение концентраци: окситетрациклина в кровянной плазме проводили микробиологическим методом и жидкостной хроматографией высокого давления.

Средная максимальная концентрация после ввода внутривенно наблюдалась в плазме слонов спустя 1 час, после 60 часов Отц в плазме не был уже установлен. После интрамускулчрной дачи была установлена максимальная конецнтрация отц 2,87 мкг.мл-1 через 2 часа после приема лекарства. Концентрация, превышаюшая 1 мг.мл -1 достигала одинакового уровня Двое суток после ввода отц. Следовательно, одного внутримышечхого применения было 
достаточно для подержки еффехтивной концентрации ОТц в хрови слонов.

\section{Acknowledgement}

The authors would like to thank Mr. Ong-Art Lawhavinit, Microblology Division, College of Veterinary Medicine, Kasetsart University, for conducting the microbiological assays. They also thank Veterinary Section, Northern Timber Working, Forestry Industry, Organization, Lumpang, Thailand, and Northern Veterinary Diagnostic Centre, Lumpang, Thailand, who provided assistance in this study.

This study was supported by Pfizer International Corporation (S.A.), Bangkok, Thailand.

\section{References}

ATKINSON, B.A.: Species incidence, trends of susceptibility to antibiotics in the United States, and minimum inhibitory concentration. In:

Antibiotics in Laboratory Medicine, Ed. Lorian, V., pp. 607-722. Williams and Wilkins, Baltimore, 1980.

BARRY, A.L. - THORNBERRY, C.: Approximative minimal inhibitory concentrations of more susceptible strains among common bacterial pathogens. In: Manual of Clinical Microbiology, Eds. Lennette, E.H., Balows. A., Hausler, W.J. and Truant, J.P., 3rd edn. pp. 498-499. American Society of Microbiology, Washington, D.C., 1980.

BENNET, J.B. - BRODIE, J.L. - BENNER, E.D. - KIRBY, W.M.M.: Simplified, Accurate Method for Antibiotic Assay of clinical specimens. Applied Microbiology, 14,1966: 170-177.

GARROD, J.P. - LAMBERT, H.P. - O'GRADY, F. - WATERWORTH, P.M.: Antibiotics and Chemotherapy, 4th edn. Churchill Livingstone, Edinburgh, 1973.

ROSENBLATT, J.E.: Antimicrobial susceptibility testing of anaerobes. In: Antibiotics in Laboratory Medicine, Ed. Lorian, V., pp. 114-134. Williams and Wilkins, Baltimore, 1980.

SHARMA, J.P. - BEVILL, R.F.: An approved method for the determination of tetracyclines in plasma, urine and tissues. Journal of Chromatography, 166 , 1978: 213-220.

SCHMIDT, M.J.: Elephants. In Fowler, M.E.: Zoo and Wild Animal Medicine, pp. 709-752. Philadelphia, W.B. Sounders Co, 1978.

SCHIFFERLI, D. - GALEAZZI, R.L. - NICOLET, J. - WANNSER, M.: Pharmacokinetics of oxytetracycline and therapeutic implications in veal calves. J. vet. Pharmacol. Therap., 5, 1982: 247-257.

Technical Information, Agricultural Development Division, Pfizer International Corporation (1977-1981). 